\title{
Turkish foreign terrorist fighters and the emergence of a new kind of radicalization
}

\section{Necati Anaz, Ömer Aslan \& Mehmet Özkan}

To cite this article: Necati Anaz, Ömer Aslan \& Mehmet Özkan (2016) Turkish foreign terrorist fighters and the emergence of a new kind of radicalization, Turkish Studies, 17:4, 618-642, DOI: 10.1080/14683849.2016.1243987

To link to this article: https://doi.org/10.1080/14683849.2016.1243987

册 Published online: 19 Oct 2016.

Submit your article to this journal $\pi$

Цlll Article views: 604

Q View related articles $₫$

View Crossmark data $\nearrow$

Citing articles: 1 View citing articles ¿ð 


\title{
Turkish foreign terrorist fighters and the emergence of a new kind of radicalization
}

\author{
Necati Anaza ${ }^{\mathrm{a}}$ Ömer Aslan ${ }^{\mathrm{b}}$ and Mehmet Özkan ${ }^{\mathrm{a}}$ \\ aDepartment of International Security, Turkish National Police Academy, Ankara, Turkey; \\ ${ }^{b}$ Department of Political Science and Public Administration, Bilkent University, Ankara, Turkey
}

\begin{abstract}
This article is an attempt to answer a number of questions asked in the literature on radicalization and extremism: What motivates foreign terrorist fighters (FTFs) from Turkey to join the Islamic State of Iraq and Syria (ISIS)? In what kind of environment does violent extremism become the choice for Turkish nationals to join ISIS in Syria and Iraq? How can Turkish nationals who join ISIS be profiled in terms of their socio-economic and cultural traits and how do these traits compare people from other nations who join and fight in terrorist organizations? Though their numbers remained minimal compared to the overall population, how can we explain the case of Turkish FTFs, when a peaceful and tolerant 'Anatolian/Sufi Islam' has reigned in the country and Muslims are well integrated in the social, economic, and political life of the country under the 13-year long rule of Islamic-oriented Justice and Development Party (AK Party)? What do these answers to these questions mean for Turkish Islam and possible de-radicalization programs? These questions will be addressed by semi-structured interviews conducted both with Turkish FTFs who have joined ISIS and with family members of some of those who have returned from fighting with ISIS.
\end{abstract}

\section{ARTICLE HISTORY Received 2 April 2016; Accepted 25 September 2016}

KEYWORDS Turkish foreign terrorist fighters; the Islamic State (ISIS); Turkish Islam; radicalization; ISIS returnees

\section{Introduction}

Though not a new phenomenon, ${ }^{1}$ the involvement of tens of thousands of foreign fighters in the Syrian war has brought the issue of foreign terrorist fighters (FTFs) to the forefront of global politics. Many publications have hitherto been produced on what motivates foreign fighters to join jihadi activity, their radicalization processes, networks of recruitment and transportation, the role of social media, and the rehabilitation and de-radicalization of these fighters. ${ }^{2}$ However, after at least two decades of global discourse on the 
subject of terrorism, the field is still in critical need of solid research on the ground in the face of new and more daunting challenges. ${ }^{3}$

While this article addresses issues covered in the existing literature, our main arguments rely on interviews with Turkish returnees from the jihadist battleground in Syria and relatives of those who lost their lives fighting for jihad in Syria. Due to its long and porous border with Syria and its vital strategic importance to confront the Islamic State of Iraq and Syria (ISIS), Turkey has been thrust into the limelight of this multi-sided and multi-party conflict. The conflict has posed pressing challenges to Turkey, as it has tried to insure that confronting ISIS did not cause the misconception that 'ISIS is a causa sui phenomenon that has suddenly materialized out of the thin ether of an evil doctrine. ${ }^{4}$ This has continued while Turkey has been cooperating with the international community to control its border and stop new jihadi recruits from crossing into Syria to join ISIS while ISIS terror attacks have increasingly hit Turkey.

At the same time, Turkey also has had to address the issue of its own citizens joining ISIS. To our knowledge, there is no field research and empirical data that exists on these Turkish foreign fighters. The Turkish case poses new and equally interesting puzzles to be solved, mainly on the ground that while it is possible to find answers in the literature to the question of why and how the young among minority Muslims living in Europe radicalize and join extremist organizations such as ISIS, ${ }^{5}$ the same cannot be said for Turkey. Low levels of political participation, disillusionment felt with governments, and a dismal record of social, economic, and political integration in Muslim-majority countries in the Middle East and North Africa may partly explain why people may radicalize in Egypt, Algeria, and Tunisia. ${ }^{6}$ Or, for some other fighters, jihad may have simply become a way of life. Dedicated to living a life of jihad or having nowhere to turn to after exiting a conflict zone (e.g. Afghanistan), many jihadists may just run from one theater of 'jihad' to another.'

If this is the case, how can we explain the puzzling case of Turkey, a Muslim-majority country, where tolerant, anti-violent 'Anatolian Islam' or 'Sufi Islam' with more emphasis on 'greater jihad' in terms of personal spiritual growth has been promoted for many decades and where Muslims are far better integrated into the social, economic, and political life of the country under the 14-year-long rule of Islamic-oriented Justice and Development Party (Adalet ve Kalkınma Partisi, AKP), but from which officially about 2000 foreign fighters have participated in jihad in the ranks of ISIS or alNusra Front? ${ }^{8}$ These contrasts make Turkey a deviant case that does not sit very easily with existing assumptions, categorizations, and arguments available in the literature. ${ }^{9}$ A carefully conducted exploratory field-work study of Turkish FTFs may provide answers, and may provoke new thoughts on the hotly debated issues of terrorism, radicalization, and de-radicalization. In addition to addressing the intriguing puzzle laid out above, we also 
discuss what this unlikely juxtaposition - moderation and high levels political participation with a starkly contrasted high number of foreign fighters means for the current and future state of Turkish Islamism.

\section{The profile of FTFs}

While some experts and analysts have long held on to the idea that 'macrosocial level factors' such as the inability of governments in the Muslim world to provide economic growth and political freedoms to their peoples are the primary causes of extremism and terrorism, ${ }^{10}$ scholars rarely hang on to this idea anymore. If economic and political deprivation was a cause for extremism, the number of Turkish foreign fighters, which has had an impressive record of economic growth and expansion of political rights and freedoms for conservative Muslims, would have been far less. Terrorists and foreign fighters may or may not necessarily come from a poor socio-economic background. ${ }^{11}$ It has been noted that these people are often well educated, may belong to middle-class families, and may not necessarily even have criminal backgrounds. ${ }^{12}$ Stenersen noted that in the case of foreign fighters in Federally Administered Tribal Areas (FATA) along the Pakistan-Afghanistan border between 2002 and 2006, the profile of foreign fighters range from highway robbers to lawyers and engineers. ${ }^{13}$ With regard to the latter, several scholars have noted that 'engineers' constituted a common breed among terrorists, including among those involved in the 9/11 attacks. ${ }^{14}$ Saad Eddin Ibrahim noted in 1980 that the leaders and many members of Egyptian terrorist organizations such as the Repentance and Holy Flight group and Technical Military Academy group were educated in universities. They also approached universities as a recruiting ground. ${ }^{15}$ The members of these two militant groups were not marginalized or alienated; they also came from cohesive families with no records of divorce. ${ }^{16}$

The motivators for terrorism and becoming a foreign fighter may also run the gamut of causes from religion, ${ }^{17}$ adventure, ${ }^{18}$ greed (money-making) ${ }^{19}$ and brainwashing. ${ }^{20}$ Feelings of existential threat one feels for an ethnic, religious and other group to which he feels attached may also play a role. ${ }^{21}$ These factors more or less correspond to Borum and Feinn's categorization of foreign fighters' psychological profiles in terms of 'revenge seeker' (anger towards a person or group) 'status seeker' (after recognition and esteem), 'identity seeker' (after belonging and meaning), and 'thrill seeker' (adventurist). ${ }^{22}$ A particularly common theme in the existing literature is the role supposedly played by veteran jihadis in radicalizing and recruiting foreign fighters as well as facilitating and coordinating their arrival in the conflict zone. $^{23}$ There is also emphasis on the role played by social ties provided by family connections, friendship, and kinship in the recruitment phase. ${ }^{24}$ 
That is, brothers and close friends may radicalize together and get recruited more easily into terrorist groups. ${ }^{25}$

The other significant matter in the literature concerns the question of what to do with returning foreign fighters, primarily in the context of the threat posed by 'returning Western foreign fighters.' There is an ongoing debate on if criminalization or rehabilitation/de-radicalization programs are the right policies to deal with the returning foreign fighters and tackle their attendant dilemmas. ${ }^{26}$ Malet thinks that reintegration programs could help states decrease the overall number of foreign fighters and curb their persistence. Otherwise, foreign fighters will have nowhere to go and nothing to do but look for other war-zones. ${ }^{27}$ For instance, if some foreign fighters went from one theater of conflict to another in the past, this may be because they had no other option. For example, the Egyptian and Syrian governments did not allow them to return home. ${ }^{28}$ According to Malet,

foreign fighters who remain unrepatriated, or merely even unassimilated into routine jobs by their home communities, are likely for reasons of economic and/or psychological displacement to remain floating regional mercenary warriors, part of a seasoned, pre-trained 'insurgent diaspora' that is particularly attractive to rebel groups. ${ }^{29}$

A considerable number of observers agree that de-radicalization programs are needed to deal with this ominous threat and that criminalizing them and therefore preventing their return will not be helpful. ${ }^{30}$ There is no definitive answer based on solid research or longitudinal statistics on how many returnees are successfully integrated into their home societies and how many became recidivists and why some de-radicalized while others went back to their old ways. ${ }^{31}$

\section{The case of Turkish FTFs}

The case of Turkish FTFs involves a major paradox. The idea that there is a 'Turkish Islam' separate from Islamic practices and understandings elsewhere in the Muslim world and that it has fed off 'the tolerance of Rumi, love of Yunus and reasonability of Hacı Bektaş-1 Veli ${ }^{32}$ is a consistent theme in some academic literature and popular writing. ${ }^{33}$ Unlike several other, more radical streams of Islamic thought elsewhere that has a top-down and communal approach, ${ }^{34}$ Turkish Islam has largely adopted a bottom-up approach and focused on the individual as a springboard to change the society gradually. If al-Qaeda corresponds to 'violence-later' method and ISIS has adopted 'violence-now, ${ }^{35}$ Turkish Islamists have largely espoused a 'violence-never' method. Several Islamist parties in Turkey contested elections and chose to work from inside the political system. In the oft-cited distinction between 'greater jihad,' which involves personal spiritual growth, and 'smaller jihad,' 
which involves military struggle to defend Islam, ${ }^{36}$ Turkish Islamists predominantly praise the former and embrace it as the more difficult and appropriate path to follow in modern conditions. ${ }^{37}$ In terms of public opinion, three large surveys done in 1999, 2006, and finally 2014 revealed that Turkish people do not desire a Sharia state ${ }^{38}$ and while 99.2 percent of Turkey's citizens reported being Muslim, ${ }^{39}$ they did not embrace a dogmatic, literal reading of Islam and lived it very 'liberally. ${ }^{, 40}$

One would expect that the development of Turkish Islam among the people in the Anatolian heartland, thanks mostly to historical, sociological, and religious sources, ${ }^{41}$ along with the supposedly moderating impact of rising prosperity in the last decade and a half, would discourage extremism. In other words, the claim that there is a 'cultural base that would push people to join ISIS' in Turkey appears unfounded. ${ }^{42}$ It needs to be kept in mind as well that the Directorate of Religious Affairs and Turkey's supposedly 'Islamist' AKP government severely criticized ISIS and fight against its ideology. ${ }^{43}$ Konya, the specific city from which we drew our sample of Turkish FTFs, complicated the paradox further. This city has been one of the AKP's strongholds as it repeatedly garnered the highest percentages of votes in this city. Konya hosts vibrant civil society organizations. ${ }^{44}$ Konya had the second lowest unemployment rate in Turkey in 2013 and ranked among the highest in export numbers as well. It ranked well above the national averages in happiness ratings and its residents were hopeful about the future. ${ }^{45}$ The likelihood of foreign fighters being supporters of the Islamicoriented Felicity (Saadet) Party, which may be considered more inflexible than the AKP on several issues (and is not represented in the Turkish Grand National Assembly), seems low as well. ${ }^{46}$ A recent poll revealed that rejection of ISIS is highest among Saadet sympathizers. ${ }^{47}$

Under all these disabling circumstances, how is it possible that hundreds, if not thousands, of Turkish nationals now fight in ISIS ranks? ${ }^{48}$ This is a formidable puzzle that deserves to be untangled. What caused these people to radicalize despite all the ideational, economic, and political barriers discussed above? What are their motivations? Admittedly, 'Anatolian Islam' had not stopped many Turks from answering calls for jihad in Afghanistan, Chechnya, Bosnia, and Kosovo in the 1980s and 1990s. ${ }^{49}$ However, a close observer called Turkish participation in these theaters as 'fringe phenomenon. ${ }^{, 50}$ Several estimates given by different observers and agencies also show that Turks do not appear in the list of countries that sent foreign fighters to Iraq after the American invasion. ${ }^{51}$ What does this paradox tell us about the future of political Islam in Turkey? Do Turkish jihadists also ridicule 'an Islam that preaches peace and harmony' and claim that this type of Islam is 'invented and promoted by the state,' as do British members of ISIS ? ${ }^{52}$ Can an accurate profile of foreign fighters from Turkey be made? Most of these are similar to the burning questions asked in the literature on radicalization. This 
study seeks to provide some answers to these critical questions at a very crucial time in regional and global politics based on interviews with ISIS defectors and their relatives in Konya.

\section{Methodology}

The very nature of our research comes with some difficulties of implementation. ${ }^{53}$ Finding a former ISIS fighter and even more difficult, being able to talk to one seemed to be almost impossible for highly understandable reasons. Aside from ethical reasons, because our research has criminal aspects attached to it, establishing a very confidential platform between our interviewees and us was very problematic. Therefore, finding ISIS returnees and/or family members of those who joined ISIS took lots of exchanges of trust building. Extracting their experiences with ISIS and time in Syria and/or Iraq was even more troubling. Through several non-profit organizations' help we managed to identify several Turkish FTFs and break the ice and enter the closed-circled world of ISIS. During our interviews we strongly stated that we did not want names or any kinds of information that would lead to the disclosure of their identity, which could ultimately jeopardize their post-ISIS life.

During our semi-structured interviews, we asked our respondents questions such as, 'What did ISIS mean to you?', 'Why did you join ISIS?', 'What kind of assignments were you given in ISIS?' and 'Why did you return?' At times, especially when their parents were present during the interviews, we mainly listened to what they had to say about their associations with ISIS and their story of disengagement. We deliberately avoided intervening too often and asking questions which might have pushed them in an embarrassing position during their family members.

Once we entered their world, we were able, using a snowball technique, to reach many more returnees and the families of either deceased fighters or those who are still continuing to fight with ISIS. In the end, we were able to converse with 22 returnees and their first-degree family members (father, mother, sisters, or brothers), altogether making up about 35 individuals. Though our sample may appear small, it marks a significant number of ISIS recruits interviewed when compared to several existing studies on radicalization and extremism especially with reference to ISIS and Syrian battleground. This number was a satisfying one for us especially considering there were only a few hundred people who joined ISIS from Konya, a city of more than a million residents. This article exclusively focuses on Turkish participation in ISIS from the city of Konya for the specific reasons laid out earlier and is therefore not concerned with what the situation is with regard to southeastern Turkey or Istanbul. The number of interviewees we acquired is, we believe, sufficient to satisfy our objectives. As we repeatedly indicated earlier, our only concern for this research was what motivated these 
individuals to join ISIS and what kind of profile we could elaborate to further understand the mindset of ISIS and its soldiers.

\section{Results}

\section{Why is ISIS attractive?}

Some media resources have reported several motivations behind Turkish FTFs joining ISIS such as religious motives, especially an Islamic eschatology claiming that Caliphate will be reborn in Damascus, money and guns, ${ }^{54}$ and adventure. There have also been cases where occasional 'jihadists' were mentally ill and high-school drop-outs. It is clear to us after our interviews, however, that ISIS has become more attractive than counterpart terrorist organizations such as Al-Qaeda due to its character of appearing a 'constructive' force. ${ }^{55}$ What makes it unique is its aspiration to immediately form a caliphate or pan-Islamic state as opposed to al-Qaeda's method of accumulating enough force and consciousness before declaring the Caliphate ${ }^{56}$ or dreams of Hizbullah in Turkey to carry out an Islamic Revolution in Turkey one day ${ }^{57}$ In this way, 'having proclaimed the establishment of a Caliphate ${ }^{58}$ in mid2014, ISIS presented itself to the international jihadi community as having achieved something al-Qaida had failed to do for twenty years. ${ }^{59}$ In other words, ISIS, unlike Al-Qaeda and others, offers a spatially organized and politically recognized life. ISIS is 'pseudo-state led by a conventional army. ${ }^{60}$ For instance, children have parks to play in ${ }^{61}$ and families of ISIS have houses to come back to after the jihad of the day or night shift. This means that the Islamic State offers actual terrain wherein one can lead a life of discipline as dictated by God, and then have a promised afterlife as a consequence of their holy struggle. ${ }^{62}$ It is in this sense 'a perfect state' based on Sharia law. ${ }^{63}$ In contrast, the remnants of al-Qaida are restricted to the Afghan-Pakistan border where living conditions for the members become unsustainable for a vibrant life and a productive territory. In contrast, ISIS, along with its allies such as Boko Haram in Nigeria and al-Shabaab in Somalia, as well as independent clusters of ISIS militants in Libya and Egypt, together occupy more physical space for a 'caliphate' than at any time within living memory. This geopolitical reason alone attracts thousands from all around the world, including Turkey for a hope that a true Islamic State is possible in Iraq and the Levant, and perhaps beyond.

\section{Jihad as a joker card}

What immediately came across in some of our interviews with returnees was that 'Anatolian extremism' is a micro and personal level of radicalization. Motivations behind radicalization and joining radical Islamic organizations 
such as ISIS were tied to individualized reasons. ${ }^{64}$ Our focus on the individual level, however, is not to claim that something is wrong with the Turkish FTFs in the psychiatric sense, as argued in other contexts by Sageman and Crenshaw. ${ }^{65}$

As for the debate on whether ISIS returnees are radicalized through group activities or the process of radicalization took place among individuals experiencing benefits of likeminded social media programs in their isolated local communities, ${ }^{66}$ our findings support both. We found that individuals, who had joined ISIS and had a tendency to extremism, had also isolated themselves from the mainstream Islamic interpretations and commonly practiced everyday religious life as mentioned earlier, and instead followed very orthodox readings of Islamic teachings and thoughts. These individuals especially enjoyed participating in group activities such as performing jumu'ah (Friday prayer) in cell-like mosques ${ }^{67}$ with their imam leading the prayer, while at the same time indoctrinating themselves through videos and films that have bombarded social media in Turkish, English and Arabic.

However, we did not see the 'normalization of jihad' - the ideal of fighting to the end as a normal way of life - that Nilsson identified with the Swedish foreign fighters in Syria. ${ }^{6}$ However, this does not mean that when ISIS sympathizers' root of radicalization, their networks, logistics and socio-cultural backgrounds are considered, there are no common traits that unify these individuals. As opposed to McCauley and Moskalenko's claim that 'typically an individual's progress into a terrorist group is slow and gradual, with many smaller tests before being trusted in more important missions, ${ }^{, 69}$ our sample's transformation and participation in ISIS was fast.

One of the characteristics of the ISIS sympathizers/returnees that support our argument is that jihad for these individuals is understood as the ultimate path to escape from their bad deeds, understood as in the metaphor of 'joker card' for cleaning of their sins and burdensome past. When we delved into these individuals' past lives, we clearly saw that they rarely practiced Islam in their pre-radicalization lives. On the contrary, they lived un-Islamic lives, mostly traumatic ones, on every level, which one can often see in marginalized neighborhoods in Turkey. This is substantiated by media reporting on other cases of Turkish foreign fighters as well. ${ }^{70}$ This ominous situation, later in their life, becomes the main source of resentment and creates a situation in which one sees no sign of ultimate redemption or change down the road to perdition. For that reason, a radical change and desire to make an immediate compensation dominates the mental string and sensational state of these individuals. Thus, the need for closing the gap between the negative past and their gloomy arrival compelled these individuals to such a radical change and motivation. A fast-track road to a better destination made it easy for them to join such a jihadist organization like ISIS. In return, ISIS offered these 
individuals a short-cut road to heaven and a spiritual redemption that otherwise looked impossible to redeem.

When we looked closely, we could easily observe that ISIS sympathizers had a tendency toward straightforward reading of geopolitical developments. They also showed eagerness to embrace interpretations of holy texts and jihadist stories of a glorified past that would reinforce their reasoning for radicalization and extremism in the end. ${ }^{71}$ Our survey of their justification for joining ISIS also supports the idea that these individuals' interpretations of Quranic texts and hadith are rigid and straightforward, leaving no room for alternative interpretations of Islamic teachings and practices. Their understanding of Islam is isolated from the historical context and severely idealized. This is in line with Sageman's observation a decade ago that the assumption that jihadis are well educated in religion is false. They often interpret the scriptures very unconventionally and they are largely self-instructed despite some self-appointed religious authorities are around. ${ }^{72}$ As British MI5's Behavioral Science Unit reported in 2008, 'far from being religious zealots, a large number of those involved in terrorism do not practice their faith regularly. Many lack religious literacy and could ... be regarded as religious novices. ${ }^{73}$

Continuing on strict readings of Islamic texts, we also observed that these individuals are dissatisfied with everyday religious practices and traditionally accepted Islamic views. Their practice of Islam is also isolated. For them, mosques are considered to be the place of opium and state-organized religion, and imams appointed by the state are the servants of that softened religion. ${ }^{74}$ Understandably, ISIS sympathizers often radically distance themselves from commonly agreed interpretations of historical events, mainstream Islamic practices and traditional Islamic schools and thoughts, mentioned earlier in the paper. Their attitude toward the Turkish Diyanet is a hostile one, accusing of the organization as being impious and statist, pacifying Muslims against the necessity for an urgent and global jihad. The same goes for Sufi Islam derived from Konya, the so called Bible belt of Islamic Turkey.

\section{Idiosyncratic Islam and Jihad}

Generally speaking, one can talk about two segments of Islamic groups in Turkey. One is connected to the state through the Diyanet and state religious schools, and the other one includes those who stayed outside of the realm of state-interpreted religion and are mostly considered to be dissident. In the past, radicalization and participation in jihad had come mostly from the second group that had not aligned itself with formal, 'approved' interpretations of Islam. However, in the case of ISIS, profiles of the returnees' show that they do not fit neatly in either of these two categories of Islamic tradition. This means that separate, distinct, unique, and self-proclaimed personalities are forming a new type of jihadism to appeal to the recruiters that work for 
ISIS. This tells us that this is a new kind of unorthodox jihad - as understood and practiced - that does not display old-fashion jihadi understandings, which had been seen during the Soviet invasion of Afghanistan, as well during as the Bosnian and Chechen wars. During these wars, a great number of jihadists joined the effort to defend so called 'Muslim homelands' for a cause that could be justified in the name of holy struggle against an undisputed foreign occupier. These jihadists, back then, had never been considered a threat to Muslims or they were never marginalized in their communities back home. For instance, when jihadists' dead bodies returned from Afghanistan and/or Bosnia to their home back in Turkey in the 1980s and 1990s respectively, their obituaries were published in local newspapers calling for local residents to join the funeral. Many members of the community joined celebrating their return, and rushed to give their last respect to deceased jihadists because in the minds of Turkish people they were not dead but instead martyrs who had submitted to a divine duty, a deed that only few were courageous to attempt to do. ${ }^{75}$

In our research, however, we found very little meaningful support from Turkish people for the ISIS jihadists of Anatolia. In other words, ISIS returnees, dead or alive, never had such divine luxury, nor enjoyed societal acceptance of their decisions. Quite the contrary of what has been claimed in many circles that 'old-school' jihadists have played great role recruiting new fighters for ISIS ${ }^{76}$ or 'they act as "connectors" to pass best practices to wannabe jihadists, ${ }^{, 77}$ we could not find support for this argument in our case study. For instance, Kaplancilar, ${ }^{78}$ one of the radical Islamist groups in Turkey, does not support or send any soldier to ISIS ranks. In one of our interviews, we noticed, for example, that one of the fathers of the returnees never used the word 'martyr' for his dead son. ${ }^{79}$ Instead, he repeatedly used the words 'casualty' or 'dead' implying that his son does not resemble those who died during the Afghan or Bosnian war and has been simply a waste. ${ }^{80}$ The son's death does not reach the level of holiness or carry a 'badge of honor' in the eyes of his own father. In another case a Turkish father calls the death of his son among ISIS ranks, a 'suicide. ${ }^{81}$ We also noticed that one recent returnee's funeral was not well embraced by his relatives, friends or neighbors, nor covered by local news media. This tells us that the ISIS phenomenon is a new kind development and a very much-unwelcomed movement for the mainstream Anatolian Islamic tradition. It also indicates that there is somehow quite a gap between what is considered to be the true jihad among families and aspiring foreign terrorist fighters in Turkey.

\section{Temperamental individuals}

When we look at the returnees' socio-cultural characteristics, we can underline that these individuals show similar themes of uneasy pasts and traumatic 
social lives that inform their tendencies toward radicalization and extremism. One common finding that we uncovered during our fieldwork is that these individuals have a criminal past (short jail time in many cases), drug problems, and traumatic family relations. ${ }^{82}$ There may be others who we did not speak to but may have joined ISIS to escape conviction in an unrelated crime. $^{83}$ Their denial of social order begins in their home against their father, mother, sisters, and brothers. The first thing they do is to deny authenticity of Islam that is practiced in their home. Then, they convince themselves that authentic Islam is only possible if the everyday state of business has been changed from secularist system to the system of sharia as advertised by ISIS. However, Marone, on the other hand, reaches a different conclusion than ours after investigating three Italian converts and states that:

their radicalization pathways did not take place in traditional settings, such as radical mosques or prisons..neither did they have criminal records nor had they ever been to prison, with the exception of el Abboubi's short detention in June 2013. By contrast, the Internet played an important role in their radicalization process, especially for el Abboubi. ${ }^{84}$

Although we believe that Marone's findings about radicals' profile might have been explanatory for the Italian converts they may be not so illuminative for the Anatolian jihadists who join ISIS as far as our findings dictates us.

Another point that we noticed during our conversations with returnees was that they seemed to be nationalist-oriented, with sharp and rigid interpretations of national events, regional developments, and political situations. During one of the interviews, one individual indicated that when he served in the Turkish army, he went there to become a martyr (die for the state by fighting to the end against a Kurdish terrorist group) but later he found himself condemning Turkey for being the 'Dar al-Harb' where Muslims are the minority and are systematically prosecuted. This idea attracted some sympathizers to join ISIS along with their wives and kids. This surely indicates that their motivation is not only about fighting and dying in the name of religion; but is also about hijra, a search for the perfect place (Dar-al Islam) to live and practice their faith freely. Thus, for an Anatolian jihadist to join ISIS, the inspiration must be more than just an opportunity to die in a holy fight but also an opportunity to live. The motto then becomes, if there is no an Islamic state where one can enjoy living, it is his/her obligation to establish one and to establish one the fight becomes unavoidable.

\section{Discussion}

As highlighted throughout this paper, the radicalization demonstrated by Turkish FTFs reveals several important elements and invites us to consider several issues. First, as it may be clear from discussions above, many 
Turkish volunteers for terrorist groups have little knowledge of religion. For example, the father of a dead terrorist indicated that the main reason why his son was lost to ISIS was because of the lack of proper religious education in Turkey. ${ }^{, 85}$ Indeed, it was strikingly obvious that the misinformed way they understand Islam makes them easy prey for recruiters who present themselves as religious authority. The two British Muslims who bought 'Islam for Dummies' before heading to Syria ${ }^{86}$ seem more to be the rule than the exception; it may be similarly valid for those who travel from Anatolia to join radical groups if a Turkish version of 'Islam for Dummies' existed. ${ }^{87}$

The lack of a critical approach and insufficient understanding of Islam indicates a clear need for a renewal of Islamic education. Here, Islamic education should not be taken at a broader level, such as education in madrasas and/or the religious schools. Rather, what is surprisingly clear is that the basic understanding of Islam lacks more than what many may imagine. For example, one of the returnees from ISIS one year later said that before going to 'Jihad,' he did not have much to do with Islam, and only after joining the ranks of ISIS, did he start to practice Islam with some Islamic education there. Strangely enough, he has changed his life back to his pre-ISIS lifestyle after coming back, and even went to the Greek islands for holiday and was partying (participating in activities that are forbidden in Islam such as drinking alcohol, etc.). ${ }^{88}$ When we asked about the very contradictory nature of his life, his answers indicated that he lacked a critical approach and even showed ignorance in basics of Islam. This also means that talking about religious reform and transformation of Islam is neither meaningful nor productive in finding a solution to the current radicalization. Contrary to what secularization thesis claimed for many years, the only way to prevent individual level radicalization is to teach religious education at the basic level in order to enable people to understand the essence of the religion. If, as we found out, there is no confirmed individual joining ISIS from the religious state schools in Turkey, the İmam Hatip Schools, then we can infer that a lack of proper Islamic teaching plays an important role in the road to combating violent radicalism.

As we mentioned previously, the little-to-none participation from ImamHatip graduates in jihad may have something to do with the education system in those schools. In Imam-Hatip schools, students are offered Islamic education such as Hadith, Tafseer (interpretation of the Qur'an), Islamic philosophy, Qur'an, Fiqh (jurisprudence), and Kalam (theology) in addition to secular sciences such as math, physics, philosophy, and social sciences. The maturation of young minds while learning both worlds creates a sort of convergence and tolerance in thought and action, and presents issues from a much larger perspective. These schools help acquire 'a well-established religious identity [which] actually protects against violent radicalization. ${ }^{89}$ This makes those graduates a very difficult prey for 
recruiters to join jihad simply because they 'believe' that they can make sense of religious text themselves and they do not have to believe what others say. What this means for a country like Turkey is that it can prevent radicalization before it is too late by having a comprehensive social structuring through a combined educational system. Blaming any religion or religious text and forcing a reformation within religion is almost equal to a regretful waste of precious human and material resources.

\section{Conclusion}

It is clear that as long as the instability in Iraq and Syria lingers on, these countries will be a safe haven for radicals, meaning that the geography of disorder and chaos will likely continue to be both reasons for radicalization and a destination for jihadists. We have investigated to what extent and how Muslims living in Anatolia, considered to be the heartland of moderate Islam, have been affected in the process. What we found is a different type of radicalization is at play, mostly at individual level. The cases we investigated demonstrate that radicalization is a growing socio-cultural problem. Lack of basic understanding of religion, wanting to take a short-cut to close the gap between an un-Islamic past and a better, redeemed future, as well as Turkey's geographic proximity to Syria seem to be the leading factors in Turkish radicalization. Although it is not possible to talk about major radicalization in Turkey because of the small number of people joining ISIS and the non-existence of public support for this kind of radicalization, there still needs to be utilization of community-based social programs to disseminate Anatolian Islam because it has always managed to dispose of radical extremisms from this geography. We need to note here that those who join ISIS do not only come from poor neighborhoods as reported in the media ${ }^{90}$ but they also come from the upper-middle class. This means that the youth is searching for a meaning in their life, and one can see that the popularity of ISIS among Muslim youth is rather dangerous response to their search.

In terms of de-radicalization and rehabilitation programs, we draw attention to the potential presented by disillusioned returnees, which is already occurring Turkey as well as other places. ${ }^{91}$ This provides a good opportunity to target those fighters who may have been in a conflict zone for the first time and thus may have come back without actually forming a strong 'jihadi belief.' De-radicalization program may then have not only a valuable opportunity to prevent the 'deed' but also modify returnees' beliefs. That is, it may be possible to reach those who were not ideologically motivated but joined in IS for other reasons such as financial ones. ${ }^{92}$ It is these returnees disillusioned with ISIS that Turkish rehabilitation programs must target with measures such as vocational training especially those that come from poorer neighborhoods. 
It is these disenchanted/disillusioned young, first-timer foreign fighters that may be very instrumental to discredit ISIS myth and narrative about supposed 'jihad' in Syria. ${ }^{93}$ These returnees as well as the former or retired foreign fighters (who fought in Afghanistan, Bosnia and Chechnya), who 'had been there and done that,' may carry far more authority than the Diyanet to form a counter-narrative and reverse fighters' radicalization process and better convince them to enter a new process of reintegration.

[A] returning fighter will have a great deal of credibility in radical circles at home, and if he argues against participation in the war, and against the alQaeda [or ISIS for that matter] narrative more generally, this is likely to be more effective than anything a government can do. (brackets are added) ${ }^{94}$

Utilizing 'retired' foreign fighters through innovative programs and forums such as the 'Afghan Alumni Forum' put in place in Indonesia to de-radicalize young Indonesian jihadists may help immensely. ${ }^{95}$

In the end, this study is a first-cut into the world of Turkish foreign terrorist fighters. We acknowledge limitations, including that we were not able to ascertain in great detail the socio-economic characteristics of the Turkish FTFs. However, we welcome future research that will delve more deeply into the questions raised in this study.

\section{Notes}

1. Thousands of Arab foreign fighters fought in Afghanistan. See Williams, "On the Trail"; Holman, "Belgian and French Foreign Fighters"; Malet, "Why Foreign Fighters?"; and Baxter and Davidson, "Foreign Terrorist Fighters."

2. Maher, "From Portsmouth to Kobane"; Higgins, "A Norway Town"; Piet, "French Jihadists"; Kern, "Dutch Jihadists"; Graham, "What's the Matter with Belgium?"; and Heyer, "The Lost Children."

3. de Bie, de Poot, and van der Leun, "Shifting Modus Operandi," 418; Weggemans, Bakker, and Grol, "Who Are They," 101; and Silke, ed., Research on Terrorism, 161-86.

4. Doostdar, "How Not to Understand ISIS."

5. Marone, "Italian Jihadists in Syria and Iraq"; Roy and Truong, "The Attractions of Jihadism"; Malet, "Why Foreign Fighters?" 109-10; "ICSR Insight: Professor Neumann's Remarks"; Maher, "The Roots of Radicalisation?"; and Barrett, "Foreign Fighters in Syria" (Soufan Group).

6. See comments by Barret, "Foreign Fighters in Syria" (Carnegie Council); Borum and Fein, "The Psychology of Foreign Fighters," 9.

7. See the report by Kyle Orton about how the Bosnian jihad shaped al-Qaeda and how Bosnia came to make 'an epicentre in shaping the jihadi-Salafist movement on the road to 9/11.' Orton, "From Bosnia to Guantanamo."

8. This is not to say that other Muslim-majority states escaped attention on the issue of foreign fighters. For instance, see Delman, "ISIS in the World's Largest Muslim Country." 
9. Another such case may be Indonesia, where the question of why only a very small minority of Indonesians are attracted to ISIS has been answered in the following terms:

Indonesia is a country that doesn't have a repressive government, is not under occupation, it's politically stable, so there's no social unrest or conflict, and the Muslims aren't a persecuted minority. So when you put all of those factors together, it's not all that surprising that it's actually only a tiny minority of even the activist population that's leaving for Syria. Delman, "ISIS in the World's Largest Muslim Country"

10. Hewitt and Kelley-Moore, "Foreign Fighters in Iraq," 213; Sageman, Leaderless Jihad, 20-1; and Crenshaw, "The Causes of Terrorism," 102.

11. Luck, "Returning Jihadis."

12. Sageman, Leaderless Jihad, 48-9; Bin Hasan, "Key Considerations," 359-60.

13. Stenersen, "Al Qaeda's Foot Soldiers," 179.

14. Gambetta and Hertog, Engineers of Jihad; Hoffman, “Today's Highly Educated Terrorists"; Stenersen, "Al Qaeda's Foot Soldiers," 183; and Sageman, Leaderless Jihad, 59.

15. Ibrahim, "Anatomy of Egypt's Militant Islamic Groups," 435-40.

16. Ibid.

17. de Bie, de Poot, and van der Leun, "Shifting Modus Operandi," 426.

18. Sageman, Leaderless Jihad, 70; Charles Lister, "Returning Foreign Fighters," 8.

19. Malet, "Foreign Fighter Mobilization," 462.

20. Williams, "On the Trail," 217; Neumann and Hofmeister, From the Desert, 301.

21. Neumann and Hofmeister, From the Desert, 31-2. According to Malet, feeling of existential threat is a must for any group to decide to send sons as well as guns to a conflict zone. See Malet, "Foreign Fighter Mobilization," 460.

22. Borum and Fein, "The Psychology of Foreign Fighters," 5; on 'seeking revenge' as a motivation, see Crenshaw, "The Causes of Terrorism," 109-10.

23. Stenersen, "Al Qaeda's Foot Soldiers," 180; Watts, "Foreign Fighters"; McCauley and Moskalenko, "Mechanisms of Political Radicalization," 421; and de Bie, de Poot, and van der Leun, "Shifting Modus Operandi," 428, 434.

24. Sageman, Leaderless Jihad, 66-7; Crenshaw, "The Causes of Terrorism," 251-2.

25. Indeed, in the case of Hizbullah in Turkey, there were some who joined the group as an entire family, which shows that one member may bring in his family with him to the organization. It is important to note that in one case this happened after the family migrated from their village to city. See Kurt, Din, Siddet ve Aidiyet, 97. On the contrary, there were also those who had tensions with their family after joining Hizbullah (p. 110).

26. On the dangers of criminalization with reference to the recent British example and comments by a counselor associated with HAYAT program in Germany, see Lister, "Returning Foreign Fighters," 5-6 and 9-10 respectively. For the risks of involved in rehabilitation and de-radicalization work if uncoordinated with intelligence and law enforcement, see comments by Levitt in de Kerchove, "Rehabilitation and Reintegration."

27. Malet, "Foreign Fighter Mobilization," 455.

28. Malet, "Foreign Fighter Mobilization," 465.

29. The United Nations Office of the Special Advisor on Africa cited in Malet, "Foreign Fighter Mobilization," 466. 
30. Porges and Stern, "Getting Deradicalization Right"; Hooper, "Denmark Introduces Rehab."

31. Malet, "Foreign Fighter Mobilization," 466.

32. Yavuz, "Is There a Turkish Islam?" 219.

33. Reed, "Religious Life," 237; Fuller, The New Turkish Republic; and Mardin, "Turkish-Islamic Exceptionalism," 148.

34. For this latter, more militant and top-down approach see Ibrahim, "Anatomy of Egypt's Militant Islamic Groups," 430, 444.

35. Nuraniyah, "How ISIS Charmed."

36. Hewitt and Kelley-Moore, "Foreign Fighters in Iraq," 213.

37. Heper, "Does Secularism Face a Serious Threat?" 414.

38. Çarkoğlu and Toprak, Değişen Türkiye'de, 16.

39. Esmer, "World Values Survey."

40. "Türkiye'de Dini Hayat Araştırması."

41. Uğur, "Intellectual Roots."

42. Daloğlu, "Turks Rumored to be Joining the Islamic State."

43. "Head of Religious Authority Denounces ISIS"; "Erdogan: Isis Aims to Destroy."

44. Aktay and Topçuoğlu, "Civil Society," 282.

45. "Seçilmiş Göstergelerle Konya 2013," 36-7.

46. Here it should be reminded that the Turkish media (traditional but especially new media) has been awash with late Erbakan's 'prophetic' comments from some time ago about a possible future dismemberment of Syria as a prelude to a following assault on Turkey, see "Erbakan Hoca Suriye Konusunda Uyarmıştı"; The current leader of the Saadet Party has been persistent in his criticism against ISIS, portraying it as an insidious Western tool to destroy Syria and Libya and divide Iraq to the benefit of Israel. "Kamalak: 'Işid'i Doğuran Sebepler Nelerdir?" This information should also be juxtaposed with the observation that there is little possibility that Saadet supporters would deviate from their party line on ISIS when their party leaders describe the war as a Zionist plot to destroy the Muslim world.

47. “Türkiye'nin Nabzı Eylül 2014."

48. Demirtaş, "More than 1,000 Turks."

49. For Turkish foreign fighters' presence in Afghanistan see Williams, "On the Trail," 234.

50. Williams, "Turks Join the Jihad."

51. Hewitt and Kelley-Moore, "Foreign Fighters in Iraq," 212; Borum and Fein, "The Psychology," 11.

52. Hassan, "Three Sisters, Nine Children."

53. This difficulty has been noted in Malet, "Foreign Fighter Mobilization," 461; Ibrahim, "Anatomy of Egypt's Militant Islamic Groups," 427.

54. 'Abu Omar says he didn't give a damn about the apocalypse, or learning the ways of "true" Islam, or joining a world-historical movement. It was 2013 and he just wanted guns and money'; see Weiss, "I Was an ISIS Jihadist."”

55. Özkan. "Batılı Bir Terör Örgütü Olarak IŞID”; Özkan, “Tezkere Sonrası”; “Türkiye'den IŞíDe Hicret Yolu”; and 'Neden IŞİD’e Gidiyorlar.'

56. Cronin, "ISIS Is Not a Terrorist Group," 93. McCants, "How ISIL Out-terrorized Bin Laden."

57. Kurt, Din, Şiddet ve Aidiyet, 150.

58. An interesting critical juncture to observe its impact on Turkish foreign fighter trends could be ISIS's declaration of Caliphate. It could be interesting to follow 
if this radical move made an impact on Turkish participants but we did not follow up on this.

59. Lister, "Jihadi Rivalry," 2.

60. Cronin, "ISIS Is Not a Terrorist," 88.

61. Yeğinsu, "ISIS Draws a Steady Stream."

62. Anaz, "IŞİD ve İdeal Mekan İllüzyonu."

63. Marone, "Italian Jihadists," 26.

64. "Radicalization Processes."

65. Sageman, Leaderless Jihad, 16-7; Crenshaw, "The Causes of Terrorism," 107.

66. Picarelli, "The Future of Terrorism."

67. Such mosques are mainly located in slum-like neighborhoods or male dominated industrial zones (Sanayi). Our two interviewers for instance were bikefixers and one of them was living with alcohol consuming father with no mother. In those mosques one would find nothing but extraordinary solidarity and comradeship as the bike-fixer explained. Imams or the other members of the cell-like mosques would take care of problems of the attendants if help is needed. One participant of such mosque explained that his need for a job is taken care of by a shopper who sells cell phones. He further stated that in the shop, he never experienced mastership as he felt like there was no boss in the store. He said that there were complete comradeship and solidarity. This took time before the individual joined the ISIS ranks. He indicated that he no longer was part of the community and the shop which disappeared sometime when he was in Syria. This practice - forming cell-like mosques- differs from that of Hizbullah in Turkey, which preferred using the Diyanet's mosques and threatened those imams who refused to cooperate. See Kurt, Din, Siddet ve Aidiyet, 52.

68. Nilsson, "Foreign Fighters," 351.

69. McCauley and Moskalenko, "Mechanisms of Political Radicalization," 419.

70. Türkiye'den "IŞİDe Hicret Yolu”; Gönültaş, “Ankara’s IS Militants Return Home." This finding is consistent with those of other research done in different places. 'Why do Lebanon's Young Men Join ISIL?'

71. In the literature, radicalization is not necessarily a violent action or unique to a non-state actor, an individual or a collective entity. A state can also have radical tendencies and violent actions toward its citizens and subjects. Furthermore, radicalization is not a certain departing point to violent extremism or/and terrorism. In other words, there is no linearity between radicalism and terrorism or one is perquisite of the other. For further clarity of the terms, see Schmid, "Radicalization, De-Radicalization, Counter-Radicalization."

72. Sageman, Leaderless Jihad, 51.

73. Travis quoted in Lister, "Returning Foreign Fighters," 8.

74. Our interviews with relatives of some ISIS jihadists; also see "Türkiye'den IŞİDe Hicret Yolu."

75. See two memoirs published by former Turkish jihadis who fought in Afghanistan, Bosnia and other jihad theatres. Yıldız, Güllerin Vedası, 8, 43, 54; Tokgöz, Cihadin Mahrem Hikayesi, 59-61.

76. Heinke and Raudszus, "German Foreign Fighters"; Hegghammer, "The Rise of Muslim Foreign Fighters," 72.

77. Malet, "Foreign Fighter Mobilization," 110; Also see Kyle Orton's argument that 'Bosnia became a hospitable operating environment for Islamist recruitment and training and both veterans of the war and people radicalized in 
Bosnia since have continued to show up in the ranks of international terrorism.' Orton, "Another Legacy."

78. For an extensive study on Kaplancılar, see Atacan, Kutsal Göç.

79. Family of another dead-ISIS member continuously called their son and daughter-in-law who decided to join the ISIS together with her husband and small child one day early in the morning as 'lost' (kayip). The family indicated that neither their son nor daughter in law prayed at home or participated fasting during Ramadan which are generally considered to be very basics of Islamic life and openly observable from outside. Although the family stated that Islam at least the very basics of it was always practiced in their home every day by the rest of the members, the family never pushed their son to join praying with them. Their son's secular life style rarely bothered the family but they never understood their son's recent change and behaviors which were alien to the family, because all of a sudden, their son and daughter in law began talking about Quran and true meaning of Islam and Islamic life. Sometimes, the father said, the whole family got into a fight about what true Islam meant till the mother intervened in the argument. During our interview, the father routinely asked these questions: 'what kind of Islam he didn't like here [in our home]?' 'What was missing here so that they have gone for the search of better Islam?' 'Who is ISIS?' 'They are bunch of terrorists who enjoy killing other believers.' And he continued and asked us if we could help him to bring his grandson back home. He strongly stated that he never missed his son or his daughter in law.

80. "Biz Koktukça IŞíD Kazanacak."

81. "Bingöl'ün Derdi IŞİD’e Götürdü.”

82. See also profiles reported in the media, “Türk'ün Cihatla İmtihanı." Once again, this profile bears some resemblance to those who joined Hizbullah in Turkey. According to Kurt, 'Hizbullah was very successful in creating a group belonging and a sacred ideal to defend among young people, some of whom happened to be drug addicts, less-educated and disadvantaged from socio-economic point of view.' See Kurt, Din, Şiddet ve Aidiyet, 56.

83. Yılmaz, "IŞID’e gitti."

84. Marone, "Italian Jihadists," 26.

85. "Biz Koktukça IŞiD Kazanacak."

86. Hasan, "What the jihadists."

87. There is a general impression based on some European foreign fighters that as opposed to 'deeply unsexy' al-Qaeda, for which, 'there is no place for alcohol or women,' and which 'attracted followers with religious arguments and a pseudoscholarly message of altruism for the sake of the ummah', ISIS was not as selective when it came to who wanted to join its caravan. See Cronin, "ISIS Is Not a Terrorist Group," 93-4. This contention has recently been supported by leaked ISIS documents, which shows that " 70 per cent of recruits were listed as having just "basic" knowledge of Shariah - the lowest possible choice.' "ISIS Recruits Have Poor Grasp of Faith." Though our sample may not allow for wide generalizations on this score, we can say that our findings confirm this contention - one does not necessarily know the basics in religion before qualifying to join ISIS.

88. This is reminder of what reportedly happened to some Turkish Hizbullah members after their leader, Hüseyin Velioğlu, who they thought was invincible, was killed by the police in 2000 . Once their leader was killed, some members, in utter shock and disbelief, who indulged in non-Islamic practices before joining 
the organization, went back to their old ways such as restarting doing drugs, returning from religion altogether, leaving prayers and becoming leftists. Kurt, 118.

89. Ibid.

90. "Türkün cihatla imtihanı".

91. Gönültaş, “Ankara’s IS Militants Return Home”; Hooper, "Denmark Introduces Rehab"; Luck, "Returning jihadis"; and Reed, de Roy van Zuijdewijn and Bakker, "Pathways of Foreign Fighters," 4. The fact that several fighters return from the battleground disillusioned is not surprising. Also see Malet, "Foreign Fighter Mobilization," 459.

92. See comments by Stone in de Kerchove, "Rehabilitation and Reintegration."

93. Hussain, "Islamic State Defectors."

94. Barrett quoted in Reed, de Roy van Zuijdewijn and Bakker, "Pathways of Foreign Fighters," 4.

95. Bachelard, "Turning Away," and Gutierrez, "How an ex-Jihadist Thinks."

\section{Acknowledgements}

The authors would like to thank to the three anonymous reviewers for their helpful and constructive comments that greatly contributed to improving the final version of this paper. They would also like to thank to several civil societies through which the authors had an access to ISIS returnees. Authors also acknowledge that their contribution to this study was equal. All remaining errors are their own.

\section{Disclosure statement}

No potential conflict of interest was reported by the authors.

\section{Note on contributors}

Necati Anaz is assistant professor at the Department of Political Science and International Relations of Istanbul University. He completed his Ph.D. in 2012 at the University of Oklahoma with the thesis 'Mapping Geopolitical Imaginations: Turkish Audiences and the Valley of the Wolves-Palestine.' Anaz previously worked at Turkish National Police Academy in Ankara (2014-16) and Necmettin Erbakan University in Konya (2012-2014). His current research interests include geopolitics of security, soft power, popular geopolitics, and geography of film audiences. He continues to publish his works in international and national academic journals. Anaz also shares his opinions in popular media and newspapers about current geopolitical crises and developments.

Ömer Aslan received his B.A. degree in political science from Bilkent University. After finishing his M.Sc. in International Relations at the London School of Economics and Political Science, he entered the Ph.D. program in political science at Bilkent University in 2010. He is now a Ph.D. candidate at the same university, working on his dissertation in the field of civil-military relations. He is also a researcher at the Institute for Security Sciences at the Turkish National Police Academy (TNPA). Among his publications are 'A Turkish Muslim Between Islamism and Turkish Nationalism: Seyyid Ahmet Arvasi [1932-88],' published in Turkish Studies, and "Unarmed" We Intervene, Unnoticed We Remain: The Deviant Case of "February 28th Coup" 
in Turkey' published online in British Journal of Middle Eastern Studies. His current research interests include the military and politics in the Muslim world, external actors and military coup d'états, and radicalism.

Mehmet Özkan graduated from Istanbul University, Faculty of Political Science, International Relations in 2002. He studied at University of Johannesburg, South Africa on African issues and holds a master in European Politics from Linkopings University, Sweden (2008) and a Ph.D. from Sevilla University, Spain (2013) with a thesis on the role of religion/culture in shaping foreign policy mentality in Turkey, India, and South Africa. He was a Visiting Student at Universidad Pontificia Bolivariana Medellin in Colombia in 2009; a Visiting Fellow at Institute for Defense and Security Analysis (IDSA), New Delhi, India in 2010; and Visiting Researcher at Cairo University in Egypt in 2011. He was also a lecturer at International University of Sarajevo, Bosnia and Herzegovina, in 2012. Between 2012 and 2014, Dr Ozkan worked as a Researcher at the premier Turkish think-tank, SETA (Foundation for Political, Economic, and Social Research) in Ankara. He was Director of the International Center for Terrorism and Transnational Crime (UTSAM) at the Turkish Police Academy between 2014 and 2015. Currently, he is Director of Turkish Cooperation and Coordination Agency (TIKA) in Colombia and Latin America. He is also the author several books including, Foreign Policy After Tahrir Revolution: (Re-)Defining the Role of Egypt in the Middle East (2011) and Turkey's Involvement in Somalia: State-Building in Progress (2014).

\section{Bibliography}

Aktay, Yasin, and Abdullah Topçuoğlu. "Civil Society and its Cultural Origins in a Turkish City: Konya.” Critique: Critical Middle Eastern Studies 16, no. 3 (2007): 273-287.

Anaz, Necati. “IŞİD ve İdeal Mekan İllüzyonu.” 2014. Star Açık Görüş, December 27. Accessed September 20, 2015. http://haber.star.com.tr/acikgorus/isid-ve-idealmekan-illuzyonu/haber-985334.

Atacan, Fulya. Kutsal Göç, Radikal İslamcı Bir Grubun Anatomisi. İstanbul: Bağlam Yayınları, 1993.

Bachelard, Michael. 2012. "Turning Away from Radical Doctrines." The Sidney Morning Herald, October 7. Accessed July 1, 2016. http://www.smh.com.au/ world/turning-away-from-radical-doctrines-20121006-275wj.html.

Barrett, Richard. 2014. "Foreign Fighters in Syria." Carnegie Council, September 23. Accessed April 29, 2016. https:/www.carnegiecouncil.org/studio/multimedia/ 20140923/index.html.

Barrett, Richard. 2014. "Foreign Fighters in Syria." Report for the Soufan Group. Accessed September 12, 2015, http://soufangroup.com/wp-content/uploads/2014/ 06/TSG-Foreign-Fighters-in-Syria.pdf.

Baxter, Kylie, and Renee Davidson. "Foreign Terrorist Fighters: Managing a Twentyfirst Century Threat." Third World Quarterly 37, no. 8 (2016): 1299-1313.

de Bie, Jasper L., Christianne J. de Poot, and Joanne P. van der Leun. "Shifting Modus Operandi of Jihadist Foreign Fighters from the Netherlands Between 2000 and 2013: A Crime Script Analysis." Terrorism and Political Violence 27, no. 3 (2015): 416-440.

“Bingöl'ün Derdi IŞiD’e Götürdü”. 2015. Al Jazeera TURK. Accessed 17 September, 2015. http://appsaljazeera.com/interactive/isid_dosya/bingol.html. 
Bin Hasan, Muhammad Haniff. "Key Considerations in Counterideological Work Against Terrorist Ideology." In Terrorism Studies: A Reader, edited by John Horgan and Kurt Braddock. London: Routledge, 2012.

"Biz Koktukça IŞİD Kazanacak". 2015. Al Jazeera TURK. Accessed 17 September, 2015. http://appsaljazeera.com/interactive/isid_dosya/isid_korkusu.html.

Borum, Randy, and Robert Fein. "The Psychology of Foreign Fighters." Studies in Conflict \& Terrorism 2016. (13 June), published online. doi:10.1080/1057610X. 2016.1188535.

Çarkoğlu, Ali, and Binnaz Toprak. Değişen Türkiye'de Din, Toplum ve Siyaset. İstanbul: TESEV, 2006.

Crenshaw, Martha. "The Causes of Terrorism." In Terrorism Studies: A Reader, edited by John Horgan and Kurt Braddock. London: Routledge, 2012.

Cronin, Audrey K. “ISIS Is Not a Terrorist Group: Why Counterterrorism Won't Stop the Latest Jihadist Threat." Foreign Affairs 94, no. 2 (2015): 87-98.

Daloğlu, Tulin. 2014. “Turks Rumored to be Joining the Islamic State.” Al-Monitor, October 1. Accessed December 28, 2014. http://www.al-monitor.com/pulse/ originals/2014/10/turkey-syria-isis-coalition-polls.html.

Delman, Edward. 2016. "ISIS in the World's Largest Muslim Country: Why Are so few Indonesians Joining the Islamic State?" The Atlantic, January 3. Accessed June 8, 2016. http://wwwhttp://www.theatlantic.com/international/archive/2016/ 01/isis-indonesia-foreign-fighters/422403/fighters-201496125229948625.html.

Demirtaş, Serkan. 2014. "More than 1,000 Turks Fighting for the Islamic Caliphate." Hurriyet Daily News, August 2. Accessed June 26, 2015. http://www. hurriyetdailynews.com/more-than-1000-turks-fighting-for-the-islamic-caliphate-. aspx PageID $=238 \&$ NID $=69867 \&$ NewsCatID $=429$.

Doostdar, Alireza. 2014. "How Not to Understand ISIS." University of Chicago Divinity School, October 2. Accessed November 19, 2015. https://divinity. uchicago.edu/sightings/how-not-understand-isis-alireza-doostdar.

"Erbakan Hoca Suriye Konusunda Uyarmıştı". 2015. Yeni Akit, July 1. Accessed September 13, http://www.yeniakit.com.tr/haber/erbakan-hoca-suriyekonusunda-uyarmisti-78576.html.

"Erdogan: Isis Aims to Destroy All Aspects of Islamic Civilization, Culture". 2015. Daily Sabah, March 4. Accessed May 17, 2015. http://www.dailysabah.com/ diplomacy/2015/03/04/erdogan-isis-aims-to-destroy-all-aspects-of-islamiccivilization-culture.

Esmer, Y1lmaz. 2012. "World Values Survey 2011.” http://www.worldvaluessurvey. org/WVSDocumentationWV6.jsp.

Fuller, Graham. The New Turkish Republic: Turkey as a Pivotal State in the Muslim World. Washington, DC: United States Institute of Peace, 2008.

Gambetta, Diego, and Steffen Hertog. Engineers of Jihad: The Curious Connection Between Violent Extremism and Education. Princeton, NJ: Princeton University Press, 2016.

Gönültaş, Hale. 2016. “Ankara's IS Militants Return Home.” Al-Monitor, July 5. Accessed July 6, 2016. http://www.al-monitor.com/pulse/originals/2016/07/ turkey-syria-isis-hacibayram-militants-return-home.html.

Graham, David A. 2015. "What's the Matter with Belgium?" The Atlantic. November 17. Accessed December 4, 2015. http://www.theatlantic.com/international/archive/ 2015/11/belgium-radical-islam-jihad-molenbeek-isis/416235/.

Gutierrez, Natashya. 2016. "How an Ex-jihadist Thinks Indonesia Can Deradicalize Terrorists.” Rappler, January 20. Accessed July 2, 2016. http://www.rappler.com/ 
world/regions/asia-pacific/indonesia/bahasa/englishedition/119625-jihadistderadicalization-jakarta-attacks.

Hasan, Mehdi. 2014. "What the Jihadists Who Bought 'Islam for Dummies' on Amazon Tell us about Radicalization." NewStatesman, August 21. Accessed September 26, 2014. http://www.newstatesman.com/religion/2014/08/whatjihadists-who-bought-islam-dummies-amazon-tell-us-about-radicalisation.

Hassan, Hassan. 2015. "Three Sisters, Nine Children, One Dangerous Journey to the Heart of Isis. What Is the Lure of the Caliphate?” The Guardian, June 21. Accessed December 12, 2015. http://www.theguardian.com/world/2015/jun/21/three-sistersnine-children-what-is-the-lure-of-the-isis-caliphate.

"Head of Religious Authority Denounces ISIS". 2014. Daily Sabah, August 20. Accessed December 16, 2014. http://www.dailysabah.com/nation/2014/08/20/ head-of-religious-authority-denounces-isis.

Hegghammer, Thomas. "The Rise of Muslim Foreign Fighters." International Security 35, no. 3 (2010/2011): 53-94.

Heinke, Daniel H., and Jan Raudszus. 2015. "German Foreign Fighters in Syria \& Iraq." Combating Terrorism Center at West Point, January 20. Accessed April 18, 2015, https://www.ctc.usma.edu/posts/german-foreign-fighters-in-syria-andiraq.

Heper, Metin. "Does Secularism Face a Serious Threat in Turkey?" Comparative Studies of South Asia, Africa and the Middle East 29, no. 3 (2009): 413-422.

Hewitt, Christopher, and Jessica Kelley-Moore. "Foreign Fighters in Iraq: A Crossnational Analysis of Jihadism." Terrorism and Political Violence 21, no. 2 (2009): 211-220.

Heyer, Julia Amalia. 2014. "The Lost Children: France Takes Stock of Growing Jihadist Problem." Spiegel International, November 6. Accessed September 23, 2015. http://www.spiegel.de/international/europe/france-struggles-to-deal-withyoung-jihadist-exodus-to-syria-a-1001254.html.

Higgins, Andrew. 2015. "A Norway Town and Its Pipeline to Jihad in Syria." New York Times, April 4.

Hoffman, Bruce. 2010. "Today's Highly Educated Terrorists.” The National Interest, September 15. Accessed June 6, 2016. http://nationalinterest.org/blog/brucehoffman/todays-highly-educated-terrorists- 4080.

Holman, Timothy. "Belgian and French Foreign Fighters in Iraq 2003-2005: A Comparative Case Study." Studies in Conflict \& Terrorism 38, no. 8 (2015): 603-621.

Hooper, Simon. 2014. "Denmark Introduces Rehab for Syrian Fighters." Al Jazeera, September 7. Accessed June 2, 2016. http://www.aljazeera.com/indepth/features/ 2014/09/denmark-introduces-rehab-syrian-fighters-201496125229948625.html.

Hussain, Murtaza. 2016. "Islamic State Defectors Hold Key to Countering Group's Recruitment." The Intercept, July 11. Accessed July 12, 2016. https://theintercept. com/2016/07/11/islamic-state-defectors-hold-key-to-countering-groupsrecruitment/.

Ibrahim, Saad E. “Anatomy of Egypt's Militant Islamic Groups: Methodological Note and Preliminary Findings." International Journal of Middle East Studies 12, no. 4 (1980): 423-453.

“ICSR Insight: Professor Neumann's Remarks at White House Summit”. 2015. The International Centre for the Study of Radicalization and Political Violence (ICSR), February 20. Accessed May 2016. http://icsr.info/2015/02/icsr-insightprofessor-neumanns-remarks-white-house-summit/. 
"ISIS Recruits Have Poor Grasp of Faith". 2016. Al Arabiya. August 15. Accessed August 22, 2016. http://english.alarabiya.net/en/perspective/features/2016/08/15/ISIS-recruits-have-poor-grasp-of-faith.html.

“Kamalak: 'Işid’i Doğuran Sebepler Nelerdir?"”. 2015. Haberler.com, January 3. Accessed September 13. http://www.haberler.com/kamalak-isid-i-doguransebepler-nelerdir-6832389-haberi/.

de Kerchove, Gilles, Jacob Bundsgaard, Doug Stone, and Matthew Levitt. 2015. "Rehabilitation and Reintegration of Returning Foreign Terrorist Fighters." The Washington Institute Policy Analysis, February 23. Accessed June 3, 2016. http:// www.washingtoninstitute.org/policy-analysis/view/rehabilitation-andreintegration-of-returning-foreign-terrorist-fighters.

Kern, Soeren. 2014. "Dutch Jihadists in Syria Pose Threat to the Netherlands." Gatestone Institute. May 15. Accessed September 12, 2015. http://www. gatestoneinstitute.org/4308/dutch-jihadists-syria.

Kurt, Mehmet. 2015. Din, Şiddet ve Aidiyet: Türkiye'de Hizbullah. İstanbul: İletişim Yayınları.

Lister, Charles. 2015. "Returning Foreign Fighters: Criminalization or Reintegration?" Brooking Institution. http://www.brookings.edu/ /media/research/files/papers/ 2015/08/13-foreign-fighters-lister/en-fighters-web.pdf.

Lister, Charles. 2016. "Jihadi Rivalry: The Islamic State Challenges Al-Qaeda." Brookings Doha Center Analysis Paper, no. 16. http://www.brookings.edu/ / media/research/files/papers/2016/01/27-the-islamic-state-challenges-alqaidalister/en-jihadi-rivalry.pdf.

Luck, Taylor. 2015. "Returning Jihadis: At Luxurious Rehab Center, a Saudi Cure for Extremism.” The Christian Science Monitor, May 17. Accessed June 8, 2016. http:// www.csmonitor.com/World/Middle-East/2015/0517/Returning-jihadis-Atluxurious-rehab-center-a-Saudi-cure-for-extremism.

Maher, Shiraz. 2014. "From Portsmouth to Kobane: The British Jihadis Fighting for Isis.” New Statesman, November 6. Accessed December 16, 2015. http://www. newstatesman.com/2014/10/portsmouth-kobane.

Maher, Shiraz. 2015. "The Roots of Radicalisation? It's Identity, Stupid." The Guardian, 17 June. Accessed August 25, 2016. http://www.theguardian.com/ commentisfree/2015/jun/17/roots-radicalisation-identity-bradford-jihadist-causes.

Malet, David. "Foreign Fighter Mobilization and Persistence in a Global Context." Terrorism and Political Violence 27, no. 3 (2015): 454-473.

Malet, David. "Why Foreign Fighters? Historical Perspectives and Solutions." Orbis Journal of Foreign Affairs 54, no. 1 (2010): 97-114.

Mardin, Şerif. "Turkish-Islamic Exceptionalism Yesterday and Today: Continuity, Rupture and Reconstruction in Operational Codes." Turkish Studies 6, no. 2 (2005): 145-165.

Marone, Francesco. "Italian Jihadists in Syria and Iraq." Journal of Terrorism Research 7, no. 1 (2016): 20-35.

McCants, William. 2015. “How ISIL Out-Terrorized Bin Laden.” Politico, August 19. Accessed December 22, 2015. http://www.politico.com/magazine/story/2015/08/ isis-jihad-121525\#.VdXrKab3ac2.

McCauley, Clark, and Sophia Moskalenko. "Mechanisms of Political Radicalization: Pathways Toward Terrorism." Terrorism and Political Violence 20, no. 3 (2008): 415-433.

'Neden IŞİD’e Gidiyorlar'. Al Jazeera TURK. 2015. Accessed 17 September, 2015. http://appsaljazeera.com/interactive/isid_dosya/neden_gidiyorlar.html. 
Neumann, Peter R., and Wilhelm Hofmeister, eds. 2015. From the Desert to World Cities the New Terrorism. Singapore: Konrad-Adenauer-Stiftung Ltd.

Nilsson, Marco. "Foreign Fighters and the Radicalization of Local Jihad: Interview Evidence from Swedish Jihadists." Studies in Conflict and Terrorism 38, no. 5 (2015): 343-358.

Nuraniyah, Navhat. 2015. "How ISIS Charmed New Generation of Indonesian Militants." Middle East Institute, January 9. Accessed June 3, 2016. http://www. mei.edu/content/map/how-isis-charmed-new-generation-indonesian-militants.

Orton, Kyle W. 2015. "Another Legacy of the Bosnian Jihad.” February 5. Accessed February 11, 2016. https://kyleorton1991.wordpress.com/2016/02/05/anotherlegacy-of-the-bosnian-jihad/.

Orton, Kyle W. 2016. "From Bosnia to Guantanamo.” January 23. Accessed January 28, 2016. https://kyleorton1991.wordpress.com/2016/01/23/from-bosnia-toguantanamo/.

Özkan, Mehmet. 2014. “Batılı Bir Terör Örgütü Olarak IŞID.” Star Açık Görüş, September 13. Accessed September 17, 2015. http://haber.star.com.tr/sondakika/ batili-bir-teror-orgutu-olarak-isid/haber-939625.

Özkan, Mehmet. 2014. “Tezkere Sonrası IŞID Politikasının Şifreleri.” Star Açık Görüş, October 4. Accessed 17 September, 2015. http://haber.star.com.tr/acikgorus/ tezkere-sonrasi--isid-politikasinin--sifreleri/haber-948071.

Picarelli, John T. “The Future of Terrorism.” NIJ Journal no. 264 (2009): 26-30. https://www.ncjrs.gov/pdffiles1/nij/228387.pdf.

Piet, Remi. 2014. "French Jihadists in Syria and Cyber-indoctrination." Al Jazeera, April 24. Accessed August 27, 2015. http://www.aljazeera.com/indepth/opinion/ 2014/04/french-combatants-syria-cyber-in-20144246186475801.html.

Porges, Marisa L, and Jessica Stern. “Getting Deradicalization Right.” Foreign Affairs 89, no. 3 (2010): 55-57.

"Radicalization Processes Leading to Acts of Terrorism". 2008. The European Commission's Expert Group on Violent Radicalization. http://www.gsdrc.org/ document-library/radicalisation-processes-leading-to-acts-of-terrorism/.

Reed, Howard. "Religious Life of Modern Turkish Muslims." In Islam and the West, edited by Richard N. Frye, 108-148. The Hague: Mouton, 1957.

Reed, Alastair, Jeanine de Roy van Zuijdewijn, and Edwin Bakker. 2015. "Pathways of Foreign Fighters: Policy Option and Their (Un)Intended Consequences." International Center for Counter-Terrorism (The Hague), April. Accessed March 3, 2016. http://www.icct.nl/download/file/ICCT-Reed-De-Roy-Van-ZuijdewijnBakker-Pathways-Of-Foreign-Fighters-Policy-Options-And-Their-Un-IntendedConsequences-April2015(1).pdf.

Roy, Olivier, and Nicholas Truong. 2014. "The Attractions of Jihadism, and a Generational Nihilism Stretching far Beyond the Muslim Sphere." Open Democracy, October 8. Accessed January 21, 2016, https://www.opendemocracy. net/can-europe-make-it/olivier-roy-nicholas-truong/attractions-of-jihadism-andgenerational-nihilism-str.

Sageman, Marc. Leaderless Jihad: Terror Networks in the Twenty-first Century. Philadelphia: University of Pennsylvania Press, 2008.

Schmid, Alex P. 2013. "Radicalization, De-radicalization, Counter-radicalization: A Conceptual Discussion and Literature Review." ICCT Research Paper, March. http://www.icct.nl/download/file/ICCT-Schmid-Radicalisation-De-RadicalisationCounter-Radicalisation-March-2013.pdf. 
“Seçilmiş Göstergelerle Konya 2013”. 2013. Türkiye İstatistik Kurumu, September 2014. http://www.tuik.gov.tr/ilGostergeleri/iller/KONYA.pdf.

Silke, Andrew, ed. Research on Terrorism: Trends, Achievements and Failures. New York: Routledge, 2004.

Stenersen, Anne. “Al Qaeda's Foot Soldiers: A Study of the Biographies of Foreign Fighters Killed in Afghanistan and Pakistan Between 2002 and 2006." Studies in Conflict \& Terrorism 34, no. 3 (2011): 171-198.

Tokgöz, Bülend. Cihadın Mahrem Hikayesi. 3rd ed. İstanbul: Ark Yayınları, 2015.

“Türkiye'den IŞíDe Hicret Yolu”. 2015. Al JazeeraTurk. Accessed September 17, 2015. http://appsaljazeera.com/interactive/isid_dosya/konyali_dede.html.

“Türkün cihatla imtihanı 7 Hürriyet muhabiri IŞİ'in izini sürdü”. 2014. Hürriyet, September 21. Accessed February 23, 2016. http://www.hurriyet.com.tr/turkuncihatla-imtihani-7-hurriyet-muhabiri-isidin-izini-surdu-27241293.

“Türkiye'de Dini Hayat Araştırması”. 2015. Diyanet İşleri Başkanlı̆̆ı. Accessed January 18, 2015, http://www2.diyanet.gov.tr/StratejiGelistirme/Afisalanlari/ dinihayat.pdf.

“Türkiye’nin Nabzı Eylül 2014: Türkiye'nin IŞID Algısı: İslam, Şiddet ve Hükümet Politikası”. 2014. Metropoll Stratejik ve Sosyal Araştırmalar. Accessed December 1, 2014. http://www.metropoll.com.tr/upload/content/files/1772-turkiyeninnabzi-eylul-2014.pdf.

Uğur, Etga. "Intellectual Roots of 'Turkish Islam' and Approaches to the 'Turkish Model." Journal of Muslim Minority Affairs 24, no. 2 (2004): 327-345.

Watts, Clinton. 2008. "Foreign Fighters: How Are They Being Recruited? Two Imperfect Recruitment Models." Small Wars Journal, June 22. Accessed August 18, 2016. http://smallwarsjournal.com/jrnl/art/foreign-fighters-how-are-theybeing-recruited.

Weggemans, Daan, Edwin Bakker, and Peter Grol. "Who Are They and Why Do They Go? The Radicalization and Preparatory Processes of Dutch Jihadist Foreign Fighters." Perspectives on Terrorism 8, no. 4 (2014): 100-110.

Weiss, Michael. 2016. "I Was an ISIS Jihadist - Until They Arrested and Tortured Me.” The Daily Beast, July 22. Accessed September 14, 2016. http://www. thedailybeast.com/articles/2016/07/22/i-was-an-isis-jihadist-until-they-arrestedand-tortured-me.html?via=desktop\&source $=$ twitter.

"Why Do Lebanon's Young Men Join ISIL?". 2015. AlJazeera, January 15. Accessed March 9, 2015. http://www.aljazeera.com/news/middleeast/2015/01/why-dolebanon-young-men-join-isil-20151145367392756.html.

Williams, Brian. G. 2006. "Turks Join the Jihad in Iraq and Afghanistan." The Jamestown Foundation, December 8. Accessed July 2, 2016. http://www. jamestown.org/single/?no_cache=1\&tx_ttnews\%5Btt_news\%5D=994.

Williams, Brian. G. "On the Trail of the 'Lions of Islam': Foreign Fighters in Afghanistan and Pakistan, 1980-2010.” Orbis Journal of Foreign Affairs 55, no. 2 (2011): 216-239.

Yavuz, M. Hakan. "Is There a Turkish Islam? The Emergence of Convergence and Consensus.” Journal of Muslim Minority Affairs 24, no. 2 (2004): 213-232.

Yeğinsu, Ceylan. 2014. "ISIS Draws a Steady Stream of Recruits from Turkey." The New York Times, September 15.

Yıldız, Bahattin. Güllerin Vedası. 4th ed. İstanbul: Özgün Yayıncılık, 2010.

Yılmaz, Aykut. 2015. "IŞID’e gitti, yaralanıp döndü tekrar savaşmaya gitti." Habertürk, July 28. Accessed February 18, 2016. http://www.haberturk.com/ gundem/haber/1108181-iside-gitti-yaralanip-dondu-tekrar-savasmaya-gitti. 